\begin{tabular}{l}
\hline MATAPPA: Jurnal Pengabdian Kepada Masyarakat \\
Volume $2 \mid$ Nomor $1 \mid$ Maret |2019 \\
e-ISSN: $2614-6673$ dan p-ISSN: $2615-5273$ \\
\begin{tabular}{|l|l|} 
(c) (1) This work is licensed under a Creative Commons Attribution \\
\hline
\end{tabular} \\
\hline
\end{tabular}

\title{
Edukasi dan Pelatihan Pembuatan Nata de Coco Sebagai Upaya Peningkatan Kesejahteraan Kelompok Masyarakat di Desa Bantan Sari
}

\author{
Mohamad Alkadri Perdana ${ }^{1}$, Hutomo Atman Maulana ${ }^{2}$
}

\begin{tabular}{ll}
\hline \hline Keywords : & ABSTRAK \\
Edukasi; & Tujuan dari pengabdian adalah untuk memberikan edukasi dan \\
Pelatihan; & $\begin{array}{l}\text { pelatihan tentang Nata de coco dan bagaimana proses } \\
\text { produksinya sebagai upaya meningkatkan pendapatan }\end{array}$ \\
Nata de Coco. & masyarakat di Desa Bantan Sari Kecamatan Bantan. Kegiatan \\
& ini dibentuk untuk memperkenalkan Nata de coco yang berasal \\
& dari air kelapa tua yang selama ini dianggap sebagai limbah \\
Corespondensi Author & kelapa, namun ternyata memiliki daya jual yang tinggi. \\
Dosen Administrasi Bisnis & Kegiatan diajukan sebagai jawaban atas kepedulian terhadap \\
Internasional, Politeknik Negeri & lingkungan dan perekonomian masyarakat di sekitar Politeknik \\
Bengkalis & Negeri Bengkalis. Target kegiatan ini adalah petani kelapa di \\
Email: & Desa Bantan Sari yang belum memahami cara memproduksi \\
hutomomaulana@gmail.com & Nata de coco yang dapat meningkatkan nilai produk dan \\
Hersaing di pasar. Metode yang digunakan adalah pelatihan \\
Received: $30-11-2018 ;$ & dan workshop. Metode pelatihan memberikan pemahaman \\
Reviewed: $20-12-2018 ;$ & tentang Nata de coco sebagai solusi cerdas dari air kelapa yang \\
Revised: $26-02-2019$ & biasanya hanya dibuang sebagai limbah kini mampu diolah \\
Accepted: $24-03-2019$ & menjadi makanan/minuman yang tak kalah nikmat dan \\
Published: $28-03-2019$ & mempunyai nilai ekonomis. Metode workshop digunakan untuk \\
& mempraktikkan bagaimana memproduksi Nata de coco hingga \\
\hline \hline
\end{tabular}

\section{PENDAHULUAN}

Desa Bantan Sari terletak di Kecamatan Bantan dengan luas wilayah $20 \mathrm{~km}^{2}$ dan terletak di pesisir pantai. Salah satu potensi pertanian yang menonjol adalah kelapa (BPS, 2017). Namun, masyarakat Desa Bantan Sari hanya memanfaatkan kelapa dengan menjual buah kelapa secara langsung. Beberapa dari masyarakat ada yang menjualnya ke pengepul dan sebagian lainnya menjualnya langsung. Selama ini buah kelapa hanya dimanfaatkan daging buahnya dan batoknya saja, sedangkan air kelapa dibuang karena dianggap sebagai limbah.

Air kelapa sangat kompatibel untuk tubuh, dapat mengganti elektrolit, menurunkan suhu tubuh, dan membantu performa olahraga
(Tih dkk., 2017). Air kelapa mengandung kadar kalium yang tinggi yang berfungsi menjaga keseimbangan cairan tubuh, menyalurkan nutrisi ke dalam sel dan membuang sampah metabolit dari dalam sel, memelihara kesehatan otot saraf, membantu sekresi insulin ke dalam darah, memelihara fungsi normal jantung, serta membantu aktivitas lambung selama proses pencernaan makanan berlangsung (Setiadi dkk., 2013). Salah satu cara memanfaatkan air kelapa adalah dengan mengubahnya menjadi Nata de Coco. Teknologi pengolahan Nata de Coco (sari kelapa. Produk ini banyak dikenal masyarakat dan memiliki nilai ekonomi yang cukup tinggi (Nurdyansyah dan Widyastuti, 2017).

Usaha Nata de Coco adalah usaha ekonomi kreatif, karena banyak menggunakan bahan baku/memanfaatkan air kelapa yang 


\section{MATAPPA: Jurnal Pengabdian Kepada Masyarakat.}

selama ini tidak banyak digunakan, bahkan hanya dibuang begitu saja oleh para penjual buah kelapa. Selain memberi nilai tambah yang luar biasa pada air kelapa, usaha produksi Nata de Coco juga untuk mengatasi permasalahan ekonomi keluarga dan sekaligus mengurangi pengangguran dengan menampung tenaga kerja di Desa Bantan Sari Kecamatan Bantan. Usaha kelompok masyarakat Desa Bantan Sari adalah usaha dari pengembangan/diversifikasi usaha perdagangan buah kelapa, dimana dengan usaha baru ini diharapkan dapat meningkatkan taraf hidup dengan menambah penghasilan keluarga melalui usaha Nata de Coco (sari kelapa/jeli). Berkembangnya usaha Nata de Coco ini akan dapat membantu program pemerintah untuk mengatasi masalah kemiskinan dengan menciptakan lapangan kerja baru dengan usaha pengolahan produk pangan.

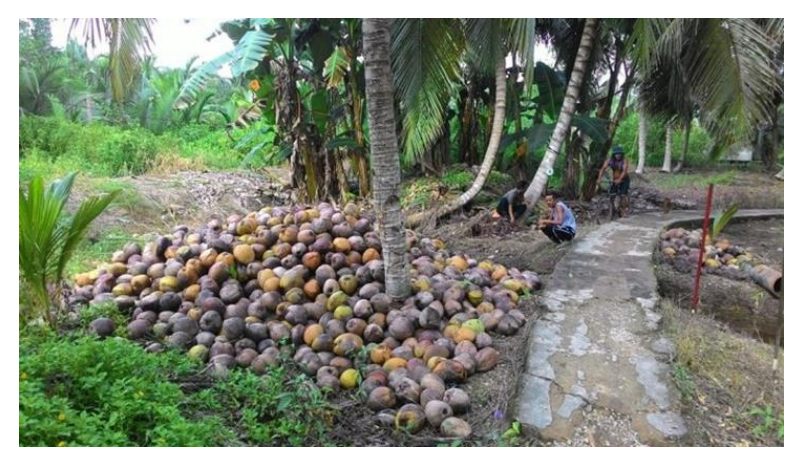

Gambar 1: Buah Kelapa yang Berlimpah

Mengembangkan usaha mikro kecil dan menengah sebagai sasaran utama pembangunan dalam rangka mengatasi masalah ekonomi masyarakat khususnya untuk pengentasan pengangguran dan kemiskinan. UMKM terbukti menyerap banyak tenaga kerja dan menggunakan hasil-hasil alam lokal untuk produksi usahanya. Dengan adanya pelatihan pembuatan Nata de Coco, akan membuka peluang baru kepada mitra kelompok usaha masyarakat desa sehingga dapat mengembangkan potensi usaha yang sudah ada, peluang mitra sangat terbuka lebar karena permintaan akan Nata de Coco sangat banyak.

Permasalahan utama yang dihadapi mitra adalah masalah produksi, manajemen dan pemasaran, permasalahan tersebut adalah: (1) Masalah produksi adalah kuantitas yang dihasilkan dikarenakan mitra belum memiliki pengalaman proses produksi Nata de coco yang baik dan benar; (2) Masalah manajemen pembelanjaan dan keuangan karena mitra tidak bisa menghitung biaya produksi dan penetapan harga jual yang layak; (3) Masalah pemasaran adalah mitra belum mengetahui cara yang efektif untuk memasarkan hasil produknya.

\section{METODE}

Upaya mengatasi permasalahan yang ada, tim pengusul menawarkan metode pendekatan yang merupakan solusi dalam kegiatan pengabdian masyarakat. Metode yang digunakan adalah pelatihan, penyuluhan, bimbingan teknis, dan pendampingan yang sesuai dengan kebutuhan dan keinginan Mitra.

Prosedur kerja atau langkah-langkah untuk mendukung realisasi metode yang ditawarkan, yaitu diawali dengan melakukan rapat koordinasi Tim Pelaksana. Rapat koordinasi bertujuan untuk melakukan persiapan administrasi. Selanjutnya menyiapkan calon mitra dan menyiapkan pelatihan, pendampingan, atau bimbingan teknis. Kemudian menyusun jadwal kegiatan pengabdian. Setelah semua tahapan persiapan terlaksana, maka selanjutnya adalah tahapan pelaksanaan kegiatan yang terdiri atas: Fasilitasi penyediaan modal, pengadaan peralatan dan bahan baku, serta pelaksanaan workshop, pelatihan, penyuluhan, bimbingan teknis, dan pendampingan. Tahapan akhir adalah pelaksanaan monitoring dan evaluasi.

Pengabdian masyarakat ini selama pelaksanaan akan terus dipantau dan dievaluasi, untuk memastikan semua materi pelatihan dijalankan dan untuk memastikan usaha pembuatan Nata de Coco dengan memanfaatkan air kelapa ini sukses dijalankan, sehingga tujuan yang telah ditetapkan bisa terwujud. Kegiatan kerjasama antara tim pelaksana pengabdian masyarakat dengan mitra akan tetap berlanjut meskipun kegiatan pengabdian telah selesai dilaksanakan. Komunikasi antar mitra dengan tim pelaksana pengabdian masyarakat tetap dilakukan untuk membantu dan mencari solusi atas permasalahan lapangan yang mitra hadapi.

\section{HASIL DAN PEMBAHASAN}

Kegiatan pengabdian dilaksanakan pada 25 September 2018 bertempat di Aula Kantor Kepala Desa. Peserta kegiatan terdiri atas anggota PKK Desa Bantan Sari dan Bantan Timur sebanyak 30 orang. Acara dimulai dengan edukasi tentang pemanfaatan limbah air kelapa yang selama ini belum dimanfaatkan oleh 
masyrakat sekitar.

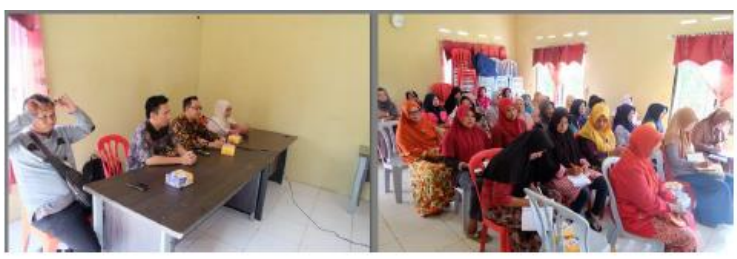

Gambar 2: Tim Memberikan Materi Edukasi Pemanfaatan Limbah Air Kelapa

Untuk meningkatkan pengetahuan dan keterampilan bagi masyarakat terkait Nata de Coco, Tim mengundang salah satu pemilik UMKM Nata de Coco di Duri yang telah merintis usaha sejak tahun 2014. Selama kegiatan, Tim memberikan pelatihan pengolahan air kelapa untuk dijadikan Nata de Coco dan menambah pendapatan kelompok PKK Desa Bantan Timur dan Bantan Sari yang dikenal memiliki banyak pohon kelapa dan banyak mengolah kelapa. Di hadapan para peserta, Tim menunjukkan cara mengolah air kelapa yang sebelumnya didiamkan terlebih dahuluu selama 24 jam untuk dijadikan bahan pembuatan Nata de Coco.

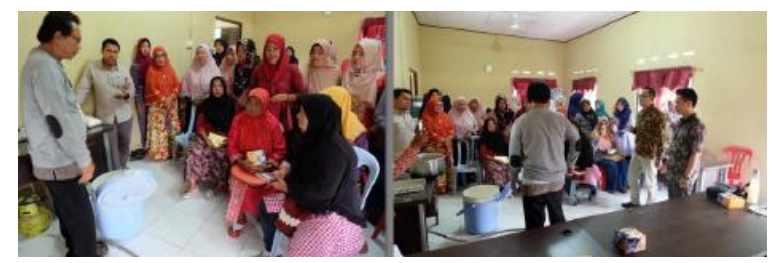

Gambar 3: Praktisi Memperagakan Tahapan Pembuatan Nata de Coco

Tahapan proses pembuatan Nata de Coco dimulai dengan persiapan alat dan bahan kemudian dilanjutkan dengan pengenalan takaran yang digunakan selama proses pembuatan. Adapun langkah-langkah pembuatan Nata de Coco adalah: (1) Memanaskan Air kelapa tua yang telah didiamkan minimal selama 24 jam hingga mendidih; (2) Air kelapa yang sudah mendidih dicampur dengan gula, ZA food grade, dan cuka; (3) Tuangkan Air kelapa ke dalam baki plastic yang telah dibersihkan dan steril dari bakteri; (4) Tutup rapat baki dengan koran dan tiriskan sampai dingin kemudian tuangkan bibit Nata de Coco; (5) Baki didiamkan hingga 7 hari baru kemudian dibuka

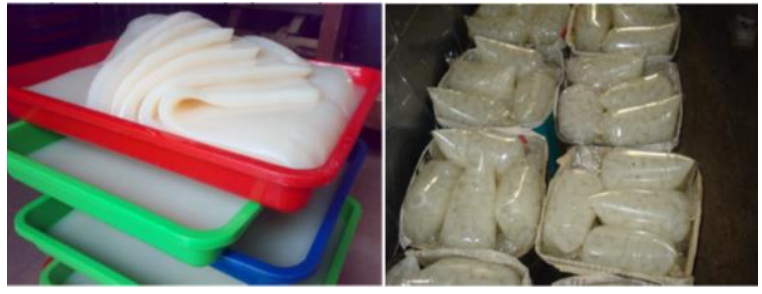

Gambar 4: Hasil Nata de Coco

Nata de Coco yang telah siap harus direbus terlebih dahulu sebanyak dua kali sebelum dapat dikonsumsi. Produk Nata de Coco yang siap konsumsi dapat dipasarkan dalam bentuk lembaran maupun potong dadu. Melalui kegiatan ini kelompok PKK dapat memanfaatkan limbah air kelapa menjadi produk yang memiliki nilai ekonomis sehingga mampu meningkatkan pendapatan.

\section{SIMPULAN DAN SARAN}

Berdasarkan pelaksanaan kegiatan edukasi dan pelatihan pembuatan Nata de Coco di Desa Bantan Sari terlihat antusiasme peserta. Hal ini ditunjukkan dengan banyaknya peserta yang mengikuti kegiatan tersebut yaitu sebanyak 30 orang.

Berdasarkan hasil dari kegiatan di atas, terdapat saran sebagai berikut, yaitu: Perlu diadakan upaya terus-menerus untuk mengembangkan variasi produk Nata de Coco yang dihasilkan. Pendampingan sertifikasi halal dari MUI dan Higienis dari BPOM terkait produk yang dihasilkan perlu dilakukan untuk meyakinkan konsumen bahwa produk bersifat halal. Selain itu juga, perlu diadakan pendampingan untuk meningkatkan keterampilan dalam hal promosi dan pemasaran produk.

\section{ACKNOWLEDGEMENT}

Kegiatan ini merupakan bentuk pengabdian kepada masyarakat yang didanai sepenuhnya melalui PNBP Politeknik Negeri Bengkalis tahun 2018.

\section{DAFTAR RUJUKAN}

Badan Pusat Statistik. (2017). Kecamatan Bantan dalam Angka, BPS Kabupaten Bengkalis.

Barlina, R. (2004). Potensi Buah Kelapa Muda untuk Kesehatan dan Pengolahannya. Jurnal Perspektif, 3(2), 46-60.

Direktorat Riset dan Pengabdian kepada Masyarakat. (2017). Panduan Pelaksanaan Penelitian dan Pengabdian Kepada 
MATAPPA: Jurnal Pengabdian Kepada Masyarakat.

Masyarakat di Perguruan Tinggi Edisi X, Kementerian Riset, Teknologi dan Pendidikan Tinggi.

Nurdyansyah, F., Widyastuti, D.A. (2017). Pengolahan Limbah Air Kelapa Menjadi Nata de Coco oleh Ibu Kelompok Tani di Kabupaten Kudus. Jurnal Kewirausahaan dan Bisnis, 21(11), 22-30.

Pusat Penelitian dan Pengabdian Masyarakat. (2018). Panduan Pelaksanaan Program Penelitian dan Pengabdian Masyarakat
Sumber Dana PNBP Politeknik negeri bengkalis, Politeknik Negeri Bengkalis.

Setiadi, P., Budiman, I. (2013). Efek Air Kelapa (Cocos Nucifera L.) terhadap Penurunan Tekanan Darah. https://repository. maranatha.edu/12340/.

Tih, F. dkk. Efek Konsumsi Air Kelapa (Cocos nucifera) terhadap Ketahanan Berolahraga Selama Latihan Lari pada Laki-laki Dewasa Bukan Atlet. 